\title{
Price of human life: Medical, legal and social aspects
}

\author{
Andrejs Vilks \\ Rīga Stradiņš University, Latvia
}

\begin{abstract}
The author of the article turns attention to the phenomenon of human life, recognizing it as the value which is hard and complicated to define. The price of a human life comprises philosophical, political, sociological and legal issues. From the legal and philosophical aspect the price of a human life is practically impossible to determine, since it is worth the highest price. Determination of the price of human life means admitting that a human is the measure of value in a certain community under appropriate socially economic conditions. Different approaches and methodologies are applied in determination of a materialized price of a human life, therefore the rating of the price is varied. In determining the price of a human life, the legal aspect is important, since it deals with the fixation of the amount of compensations in cases of an individual's loss of life and calculations of the insurance costs.
\end{abstract}

Key words: a human, price of life, investigation methods, values.

\section{Introduction}

The price of a human life has never been properly assessed, and a man as a value has neither been sufficiently learned nor protected. Though seeming illogical but, if the human life is under-evaluated, more extensively and lethally endangered, then it gives way to different approaches and methods to be developed in order to determine the man like a value (price) of material and social substance.

Extensive research is being carried out in different countries on the value of a statistical life (VSL). Determination of material values of a human's life is claimed to be immoral, since it is having the highest and even undeterminable value. However, determination of the price of a human life is essential in legal proceedings, fixing compensations in cases of bodily injuries or even in lethal cases; in life insurance and social security; by planning and implementing health care and human security measures.

\section{Aim}

The aim of research is to learn the approaches in determining the price of a human life, to investigate specific methods for calculating the price of life and the potential value of human life, and also to analyze the investigation perspectives of the problem.

\section{Results}

It is important to admit, that on one hand any approaches, methods and attempts to calculate the price of human life, especially from economic and political aspect, might be considered 
as unacceptable and immoral. Why? First of all, the human life is the greatest value and is undeterminable and cannot be assessed. Secondly, the human life is determined according to the age, professional affiliations, sex, acquired education, as well as the place of living and socially economic situation in the respective country. The price of human life is calculated also according to a person's income and job position. To what extent is it acceptable? Statistics, mean indices and formulas used in calculations seem not to be related to our emotions and the scale of our moral values.

On the other hand, however, lack of calculations fixing the price of a human's life and the corresponding methods can result in immoral and deeply problematic situation. How to evaluate the price of hundreds of lost human lives in traffic accidents? How to calculate the amount of remuneration for lost lives at the working place (in construction sites, in forests)? Or, what losses have to be covered and what compensations paid to the relatives whose dear ones have been killed in military missions or in warfare, or in terrorist acts? Would not there be still ways and need to define some specific approaches, as well as to recognize methods for determining the price of a human's life?

\subsection{Historical aspects of the price of a human life}

In ancient Egypt male slaves were worth of approximately 32,000\$ (in current costs). During Roman Empire a gladiator (a slave) was worth 2,080\$, respectively. In America in 1850 -a 10 -year-old boy (a slave) was worth $8,100 \$$. In comparison, nowadays, a child in Indonesia is worth 160-250\$ [13]. Essentially, it was not the price of a human life, but it was the man's own material value. But, to a certain extent, a human's material value was equivalent to the price of a human life. A potential price of a human life in Latvia has been set, as well. According to a lawyer Gita Miruškina' data, the lowest price for which a girl has sold herself by fictitious marriage is 200 EUR [4].

For the first time the approach in evaluation the price of a human life was developed in the United Kingdom and the USA in the 50ties of the 20th century. The development of the method was targeted at assessing the costs in cases of traffic accidents, carried out by the National Highway Traffic Safety Administration (NHTSA) and Transport Research Laboratory (TRL). The price of a human life was attributed to the costs, the products developed and services rendered, which could not be acquired, or received in lethal cases, or as a result of disabilities in traffic accidents [18]. The price of a human life, in fact, corresponds to the amount of human capital which can be equal to the value added what a man is accomplishing during his/her lifetime.

In the 60ies of the last century, the average American or British driver was found to estimate his/her life six times higher, in comparison to the total income, which a person could acquire by working till the end of life [21]. Taking into account these data, it has been calculated, that the average cost of a Luxembourg inhabitant was worth $\$ 5.000 .000$, correspondingly - Swedish 2600000, 2400000\$ - the UK inhabitant and Portuguese $2300000 \$$. The estimates mentioned are based on the approach that the price of a human life is attributed to his/her wages earned during the lifetime. This approach provides that the average price of a human life is similar to the corresponding average national salary and the likelihood of death within a year. The U.S. Office of Management and Budget estimates the price of a human life in the range of 7000000 to $9000000 \$$ [11].

\subsection{Methods of calculating the human life}

In recognizing the price of a human life one can use different methods (resource use; statistical methods; a method to determine the human capital; questionnaires, etc.). In the 
fields of medicine, jurisprudence, economy, informative technologies and social services the price of a human life can be estimated on the basis of the respective work priorities and specificity of the field [16]. In some countries special investigation methods are used. For example, in Great Britain QALY index is used [21] - a human year of life in good health ( $£ 30$ thousand). The price of a human life defined by EK is 3.1 million EUR, the USA -4.8 million USD. In the cases of decline of life expectancy due to the death by EK calculations one year bears losses of 73000 EUR, which is related to a human's age. The human life in Latvia is worth: 320600 EUR [9] according to the calculations of "Harmonised European Approaches for Transport Costing and Project Assessment"); 323400 EUR. Calculations of the Road Safety Department show that the state suffers losses of 231000 Ls (the price of life -231 thousand Ls) due to victims in traffic accidents [5]. The price of a human life is determined correspondingly to his/her age, sex, educational level, acquired qualification and social status.

Demographic method. The price of a human life is estimated on the basis of the balance of material benefits stored, as well as used by a respective generation. The respective generation' profitability, its ability to provide for and store material values for future generations are determined.

Statistical evaluation of the price of an average human life, considering the usefulness theory. Premature death, loss of work abilities point to the decrease of a human's public usefulness. Public usefulness promotes the rise of an individual and national income. The human economic usefulness is calculated also by determining Gross domestic product per capita. An individual's premature death, especially the number of violent deaths, can decrease the GDP. R. Renemanis in his thesis, by giving socially economic assessment of the Latvian oncology system [12], using DALY method, admits that mortality and incapacity for work (including disability) impose a burden to the national economy.

Method of investment readiness in life provision. Setting one's life and health values, people are ready to invest into provision of their life and health. Life and health security is organized basing on the individual assessments, by determining one's own price of life, by personal life insurance, and also by corporative and collective insurance. If in the first case the investments into the life insurance depend on a human's material capacities and subjective wishes, then in the corporative insurance cases, the life and health insurance in some fields is regulated by some laws and is done imperatively.

Actuary approach method. This is the method which is applied to estimate the prognosis of probability distribution, based on appropriate statistical databases when determining the quantifiable values. The price of a human life is calculated on the basis of average GDP indices. When calculating the price of a human life and using mathematical formulas, and determining the potential human life expectancy (death), there is calculated a human's material value. Actuary approach method is most commonly used in the human life and health insurance.

Legal approach. The price of a human life is set also in the existing legal acts. Thus, the Law, adopted on May 18, 2006 "On compensation for victims" Article 3 says [10], if a person has died, or a victim has died as a result of violence and no state compensation has been demanded, or it has been demanded and not received, a person who has been recognized as a victim in the respective criminal process has the right to get the state compensation. The right to receive the state compensation is in the case, if a deliberate criminal offense is inflicted, resulting in a person's death. Applications to get a state compensation are accepted and compensatory payments are provided for by the Legal Aid Administration [8]. Article 7 of the Law "On compensation for victims" states the maximum amount of the state compensation. Part 1 of the mentioned Article says that the maximum amount of the compensatory payment to one crime victim is five minimum monthly salaries as set by the Republic of Latvia. 
Table 1. Activities of the Legal Aid Administration (LAA), providing disbursements (compensatory payments) in cases of a person's death (2014-2016).

\begin{tabular}{|l|r|r|r|}
\hline LAA activities & $\mathbf{2 0 1 4}$ & \multicolumn{1}{|c|}{$\mathbf{2 0 1 5}$} & \multicolumn{1}{|c|}{$\mathbf{2 0 1 6}$} \\
\hline Total number of applications & 655 & 717 & 770 \\
\hline Number of decisions on compensatory payments & 564 & 636 & 694 \\
\hline Including decisions on a person's death & 129 & 121 & 141 \\
\hline State compensatory payments to victims (EUR) & 562202 & 664521 & 764521 \\
\hline including cases of a person's death & 166134 & 170590 & 200123 \\
\hline $\begin{array}{l}\text { Average compensatory payment in a case of } \\
\text { a person's (EUR) death }\end{array}$ & 1288 & 1410 & 1419 \\
\hline
\end{tabular}

The amount of the compensatory state payment is calculated, considering the amount of minimum monthly salary which exists at the moment when a person is recognized as a victim. The compensatory payment is paid out $100 \%$, in the case of the death of a person. In the year 2017 the maximum amount of the compensation paid out to a person's relatives, who have been recognized as victims of a criminal offense resulting in a person's death was 1900 EUR (the Legal Aid Administration). In 2014 it was not allowed to exceed 1600 EUR, in 2015 1800 EUR, but in 2016 - 1850 EUR. According to the Law "On compensation for victims" the price of a human life does not even reach 2000 EUR. Actual disbursements to the relatives (victims) in a case of a person's death, related to a deliberate violence, are even lower.

The data analysis, as shown in Table 1, allows us to draw some conclusions which deal with tendency of crimes, violent deaths and compensatory payments as a result of a victim's death:

First of all, violence in Latvia within the period from 2014 to 2016 has decreased (by $5.9 \%$ ); secondly, the number of cases of intentional murders has decreased (from 85 in 2014 to 65 in 2016); thirdly, despite the mentioned tendencies, the number of persons who had applied to the Legal Aid Administration to compensate the losses incurred due to violence, including the death of a person, has increased (in 2016, in comparison to 2014 - by $9.3 \%$ ); fourthly, the average sum of the compensatory payment in the case of a person's death makes only from $76.7 \%$ (in 2016) to $89.5 \%$ (in 2014) of the compensatory payment amount as set in the Law "On compensation for victims". The tendencies mentioned are sufficiently contradictory, which, on one hand witness the decrease of crimes, including the decrease of murders, while, on the other hand, - the increase of the range of persons who are applying for the compensatory payments, death cases including. In the same case, the average statistical index of the paid out compensations in death cases decreases. We can conclude, that taking into account the mentioned aspect, the price of a human life in relation to compensatory payments in person's death cases, decreases. The tendency mentioned is not grounded. From morally-ethical, economic, and also legal aspect, the compensatory payments in a person's death cases should increase.

We have to admit, that except for the envisaged compensations to victims as set in the law, including the cases of murders, one can recover also the moral damage through legal proceedings.

An example on determining the moral compensation is the case of murdering E.P. [6]. In May, 2012, 23 years old Elīna P. was extremely cruelly and brutally murdered in Riga. According to the Criminal Law, Article 116, 25 years old J.G. was sentenced to imprisonment for 9 years and 10 months. The court decided to recover material compensation of 14000 EUR from the convicted person for each of the murdered girl's parents and 12000 EUR as moral compensation for the victim's sister. E.P.'s life was estimated 40000 EUR worth. The murdered girl's father rightly pointed to the fact, that the daughter's loss cannot be expressed in money terms. Human life has to be rated not by the amount of compensation, like it is done 
Table 2. Insurance service market in the field of life insurance (2014-2016).

\begin{tabular}{|l|r|r|r|}
\hline & \multicolumn{1}{|c|}{$\mathbf{2 0 1 4}$} & \multicolumn{1}{|c|}{$\mathbf{2 0 1 5}$} & \multicolumn{1}{c|}{$\mathbf{2 0 1 6}$} \\
\hline Number of persons who have insured their life & 178853 & 202471 & 228500 \\
\hline Signed premium for life insurance & 82274541 & 89717494 & 97497556 \\
\hline Paid compensations for life insurance & 39832209 & 44869608 & 51552785 \\
\hline Average amount of premium for life insurance & 460.00 & 443.11 & 426.68 \\
\hline Average compensatory payment for life insurance & 220.70 & 221.61 & 225.61 \\
\hline
\end{tabular}

in setting the price for a special breed puppy, but like a priceless value. In the courtroom the murdered girl's father M.P. said, that "We, as parents, have to struggle till the end, making use of all possible ways. No money outweighs the suffering of parents whose child has been killed. I want to give a signal that a child's life is worth much more than that of a puppy. Man is a value!"

By assessing the price of a human life, as well as an individuals' attitude to one's own life, the aspect related to the life insurance seems quite peculiar. According to the data of the Latvian Insurance Association, the number of persons who have insured their life lately is increasing [2]. In 2016, in comparison to 2014, the number of persons who have insured their life has increased by $27.5 \%$, the number of signed premium for the life insurance, in its turn, has increased by $18.5 \%$ (see Table 2).

We can conclude that the life insurance lately is not only increasing, but has covered the greatest insurance services segment as well. At the same time the number of signed premium in the above-mentioned type of insurance is increasing as well. The amount of remunerations received by clients is also increasing (in 2016-51.6 million EUR, $+15.4 \%$ in comparison to 2015). In the last years Latvian citizens had started to appreciate their life much higher than before. It is quite possible that such a tendency is determined by the possible escalation of subjective life-endangering factors, the increase of the demographic group representing the senior age population, the risk of outbreak of different diseases, etc., all this causes worries as to the threat to one's health.

As admitted by J. Abašins, president of Latvian Insurance Association, in the Western Europe the life insurance is the dominating one and covering $50-70 \%$ of the total insurance market. Human life is considered to be a much higher value than movable and immovable property. Thereby, we can say that there is a difference between the post-Soviet value system and the Western European traditional culturally-historical system. In the context mentioned, the insurers are not interested in persons over 55 years of age, who are quite commonly perceived as "the walking dead men". In earlier times there had been kept a coffin in the atticready for hard times. Such a kind of long-term thinking would be useful today as well [1].

The price of a human life can be evaluated, to a certain extent, by the medical criteria too. On one hand, they would include the expenses for health care, payments for medical and pharmaceutical services. Such expenses are quite individual and related to a series of different individual needs (inheritance, day mode, diet, type of work, etc.). With age the expenses for medical services and the use of different medicines for provision of good health increase. On the other hand, we have to consider the medical aspect, in which by recognizing the human as a value, one has to deal with the value of human organs as well, when looking for the donors and when undertaking the organ transplantations.

Already in 2002, while studying the human trafficking problem, we touched upon the human organ and tissue trafficking aspects [15]. More than fifteen years ago the price for the internal organs as evaluated by the people was 50-50 000 Ls (70-70 000 EUR). At present we have not got any data on how the people appreciate their health and for what sum of money they would like to sell some of their internal organs. At present the human organ 
prices are varied. For instance, the human retina costs from 5000 to $100000 \$$, spinal cord is evaluated from 15000 to $300000 \$$, part of the liver $-50000 \$$, price for the kidney from 30000 to $120000 \$$ (depending on the donor's age and health), the ovum $-650-1000 \$$, the heart - about $250000 \$$.

The known Russian criminologist Vladimirs Ovčinskis admits, that at present it is dangerous for criminal structures to develop the people killing conveyor with an aim to get the necessary organs from their bodies, since it is troublesome and time-consuming. But, now a new segment for the human organ restoration or transplantation is being organized the human organ and tissue self-cloning. Cloned organisms or their elements might substitute damaged human organs, replacing criminal organ or tissue extraction [20].

On March 8, 2005, the UNO adopted the Declaration Nr.59/280 "On Human Cloning" [14], by which Member States were called on to adopt all measures necessary to prohibit all forms of human cloning inasmuch as they are incompatible with human dignity and the protection of human life. However, research ethics in respect to reproductive and therapeutic cloning is perceived and appreciated differently.

At the same time more and more commonly $3 \mathrm{D}$ printers are used for different organ 3 dimensional printing. To do the necessary organ printing one needs: cells; biomaterial matrix and special culture medium. Cells are placed on the biomaterial and then kept in a special culture medium [7]. Now 3-D printer is successfully producing animal bone elements, muscles, etc. The USA medical centre Wake Forest has developed the methods in the use of 3 -D printer. Thereby, the number of human murders to get their organs or tissues for further transplantation might decrease [3].

Another, slightly different approach while evaluating the human price is based on the chemical elements which make up the human body. The French chemists identified the chemical substances which are in the human body. According to the estimates, the human body contains $860 \mathrm{~g}$ phosphorus, $300 \mathrm{~g}$ sulphur, $210 \mathrm{~g}$ potassium, $100 \mathrm{~g}$ sodium, as well as one gram magnesium, iron, fluorine, zinc, copper and several milligrams of iodine, cobalt, manganese, molybdenum, chrome, selenium. A human body possesses only $5-7 \mathrm{~kg}$ of solids and $90 \%$ water. Thus, considering the present costs of chemical products, we can judge, that substances of which the human body consists of, do not exceed $145 \$$. Medical approach indicates that the human body, which consists of functionally very important organs, is undoubtedly much more valuable than the value of separate chemical components. Estimates show that by selling each body organ or tissues separately, all in all, it may reach up to $45000000 \$[19]$ !

It is also possible to learn the price of the human life in relation to the still unborn persons. One can state that possible harm which occurs as a result of legal and criminal abortions. In democratic society the human body is recognized to belong solely to a person himself/herself. It can be controlled only by a person himself/herself and not by any other forces. However, from the theological aspect - abortion is not only a sin, but a murder as well. Not only an unborn baby is murdered, but the person doing it gets deformed by performing abortion according to the spiritual value system. No doubt, that there can be exceptions in these cases too: a newborn might have a form of a severe disease; childbirth may be endangered by complications and the mother's life as well, etc. Relatively, a still unborn baby's price of life can be equalled to an average value of a human life.

When referring to the price of a child's health, in some sources we can read, that embryos of the unborn babies are used in catering, considering it as a special dish. The price of the respective food is from 430 to $570 \$$ [17]. From criminological and morally-ethical aspects it would be unacceptable.

It is possible to choose different approaches and methods for determining the prices of the human life. When applying them, and by considering a person's age, level of education 
and other parameters, we can define the average, as well as the most exact person' price of life. And yet - does the calculation of the price of the human life make a man more valuable? Does the society, by declaring a man as a basic value, sufficiently protect and take care of this value?

\section{Conclusions}

The human life has the highest value. However, its usefulness in the process of historical evolution of the civilisation, as well as within diverse national frameworks, has been perceived and estimated differently. In calculating the price of a human life, various methods are applied and their use can identify also quite different human values. Calculations of the price of the human life are most commonly used when applying for insurance services, by receiving compensatory payments for losses or moral harm in the cases of death. Single human organs or tissues are in great demand especially for transplantation operations. But the advancement of modern technologies contributes in succeeding to get them in an unconventional way.

\section{References}

[1] J. Abāšins, Kā apdrošināt staigājošo mironi jeb cilvēku pēc 55? Available online at: http://www.delfi.lv/news/comment/comment/janis-abasins-kaapdrosinat-staigajoso-mironi-jeb-cilveku-pec-55.d?id=48106795

[2] Apdrošinātāji pērn prēmijās parakstīja par 5, 7\% vairāk - 395 miljonus. Available online at: http://financenet.tvnet.lv/nozares/645622-apdrosinataji_ pern_ premijas_ parakstija _ par_ 57_ vairak_ 395_ miljonus

[3] A 3D bioprinting system to produce human-scale tissue constructs with structural integrity. Available online at: http://www.nature.com/nbt/journal/v34/n3/ full/nbt.3413.html

[4] Cilvēka cena - 200 eiro. Available online at: http: //www.irlv. lv/en/2015/9/16/ cilveka-cena-200-eiro)

[5] Dzīvības cena - 231 tūkstotis latu. Available online at: http://www.delfi. lv/news/national/criminal/dzivibas-cena-231-tukstotis-latu.d?id= 5610029

[6] A. Gabre, Vecāki vēlas panākt, lai bērna dzīvība ir vērtīgāka nekā kucēna. Neatkarīgā rìta avīze, 2017. gada 24. janvāris

[7] E. Girons, LOR orgānu 3 dimensionāla printēšana. Available online at: https:// www.slideshare.net/Klagisa/lor-orgnu-3-dimensionla-printana

[8] Juridiskās palīdzības administrācija. Available online at: http://jpa.gov.1v/pub/?id=64

[9] Latvijā un Lietuvā cilvēka dzīvībai ir zemākā "cena” Eiropas Savienībā. Available online at: http://www.tvnet.lv/zinas/arvalstis/337458-latvija_ un_ lietuva_ cilveka_dzivibai_ ir_ zemaka_ cena_ eiropas_ savieniba

[10] Likums "'Par valsts kompensāciju cietušajiem", Available online at: //https:// www. google.lv/?gws_ rd=ssl\#q=\%E2\%80\%98\%E2\%80\%99Par+kompens $\%$ C4\% 81 ciju+cietu $\%$ C5 $\%$ A1 ajiem $\%$ E2 $\% 80 \% 99 \%$ E $\% 80 \% 99+\& *$

[11] F. Partnoy, The Cost of a Human Life, Statistically Speaking (2012). Available online at: https://www.theglobalist.com/the-cost-of-a-human-life-statisti cally-speaking/ 
[12] R. Renemanis, Latvijas onkolog̣ijas sistēmas sociāli ekonomiskais izvērtējums Eiropas regionos. Promocijas darba kopsavilkums. Daugavpils, 2015

[13] The Cost of Human Life. Available online at: http://humancost .info/

[14] United Nations Declaration on Human Cloning. Resolution adopted by the General Assembly A/RES/59/280. Available online at: http://www.unescobkk. org/fileadmin/user_ upload/shs/BEfiles/chapterE.eng/E8.2E.pdf

[15] A. Vilks, Cilvēku un viņu orgānu tirdzniecība: kriminoloğiskās, politiskās un sociālās problēma. Ieskats XXI gadsimta kriminālajās reālijās. Rīga (2002)

[16] W. Viscusi, Kip. The Value of Life: Estimates with Risks by Oc-cupation and Industry. Harvard Law and Economics Discussion Paper No. 422. May 2003

[17] В китайских ресторанах можно заказать блюдо из неродившихся младенцев. Available online at: http://vlasti.net/news/129846

[18] Жизнь - не бесценна. Available online at: https://iq.hse.ru/news/ 177670487.html

[19] Медики подсчитали рыночную стоимость человеческой особи. Available online at: https://oko-planet.su/phenomen/phenomennews/40287-medikipodschitali-rynochnuyu-stoimost.html

[20] В.С. Овчинский, Криминология и биотехнологии. Москва. Норма

[21] Руденко П.Цена человека. Available online at: http://kommersant.ru/ doc/1654518 (2005) 